Milka Car

\title{
We "were neither Croatians, nor Illyrians nor Slavs, but "imperial royal frontiersman'". On the phenomenon of the border in August Šenoa and Miroslav Krleža
}

Keywords: border phenomena, Austro-Hungarian Empire, post-imperial age, August Šenoa, Miroslav Krleža

DOI: $10.4312 /$ ars.13.2.40-63

\section{Introduction}

The topos of border is one of the conductive motifs found in the literature that emerged on Croatian lands, and can be traced back to the times of the incursion of the Ottoman military forces into Europe, from the early modern period until the $19^{\text {th }}$ century and the introduction of the Military Frontier as a line of defence against the incursion from the Ottoman Empire: "From the end of the fifteenth century, when the Ottoman conquest reached Croatian lands, the conviction that Croatia was a kind of antemurale Christianitatis - the bulwark of Christendom - become deeply integrated in the Croatian culture" (Goldstein, 2005, 79) as a consequence of centuries-long warfare on the Hungarian, Habsburg and Venetian borders with the Ottoman Empire. In other words, for a long time in Croatian territories there had been an understanding of one's own peripheral position at the intersection of three empires. ${ }^{1}$ Literary texts from that period therefore reflect different cultural inputs and, in many ways, define the politics of identity. By referring to the description of literary space or spatial structures in aesthetic objects in correlation to the topological turn I will portray the connection between the understanding of one's own peripheral position and emerging and competing national narratives. Jurij M. Lotman understands the symbolic semiotics of space in literature as a result of culturally specific uses of signs, since every "culture begins by dividing the world into 'its own' internal space and 'their' external space"2 (Lotman, 2001, 131). Lotman also sees an analogous relationship between texts as abstract models of reality in his notion of "symbolic spaces" and reality phenomena,

1 On the fenomenon of border in early new modern epoche see Roksandić, 2003.

2 "Because the semiotic space is transected by numerous boundaries, each message that moves across it must be many times translated and transformed, and the process of generating new information thereby snowballs." (Lotman, 2001, 140) 
such as the border in this case: "It is so easy to make geography symbolic, as we see when a geographical point becomes subject to persistent wars or national and religious conflicts, or when it acquires different value to different national traditions" (Lotman, 2001, 177). Combining theses from symbolic geography and semiotics of space with postcolonial and post-imperial discourses will reveal complex relationships at the intersection of different cultures - the South Slav, Germanic and Ottoman, as well as the gradual and ambivalent birth of national narratives from the imperial framework. I am referring to Anthony D. Smith's thesis about "nationalist space visions" (Smith, 1987, 184 ) in his chapter on "Poetic spaces: the uses of landscape", where Smith investigates the "naturalization of historic sites and monuments" (Smith, 1987, 186) and forms on national mythology or "myth of ethnic origins and descent" (Smith, 1987, 192). National mobilization proceeded by way of several interrelated processes and often had the character of protest against the old imperial regime. National mobilization tended to be a quest for political and economic rights, but here it was primarily a quest for cultural privileges such as education and administration in the vernacular. At the beginning there had been a revival of the mythologized national history, as expressed through the search for poetic spaces and the cult of the past. The border as a phenomenon of poetic space engaged in the process of nation-building must be seen as a fluid and diffuse realm of cultural diversity, in the way Andre Gingrich explains the etymology of "frontier", "threshold", "boundary", "border" or "limit" (Gingrich, 2016, 159). I will hence point to semantic turns in the representation of the Military Frontier as a form of national border myth in the conceptualization of national and symbolic identity in late $19^{\text {th }}$ and first half of the $20^{\text {th }}$ century (Žanić, 2005, 35-76), whereby "Triplex Confinium has a legitimate place" (Rieber, 2000, 15) in building a model of comparative frontier societies.

In late Austro-Hungarian Monarchy, the "term 'borderland' rarely referred to a border between sovereign states. Instead, borderlands usually referred to internal national or cultural frontiers that allegedly separated - or conjoined - imagined nations, cultures, or even civilisations along shared peripheries" (Judson, 2013, 123). The professor of Russian studies Pål Kolstø links such conceptions about the border to mythologems that follow the process of nation-forming and thus provides a typological classification describing "the myth of being antemurale" (Kolstø, 2005, 19 ), in which "the group is now included in some larger and allegedly superior cultural entity that enhances its status vis-à-vis other groups who do not belong" (Kolstø, 2005, 19), which can be interpreted as the process of Othering developed by strategies of symbolic nation-building in South-East Europe and late Imperial Austria. In cultural geography, Othering is described as "a process [...] through which identities are set up in an unequal relationship" (Crang, 1998, 61). Regarding the fact that otherness 
belongs to the realm of discourse and difference to the realm of fact, the verb form "Othering" describes processes of exclusion by categorization of a group outside the nationally defined space or even realm of culture (Said, 1979). In post-colonial thought, such politically marked self-identification by means of dissociation was developed under the notion of Othering. Such Othering describes mechanisms by which masses become convinced that "we" are a nation, while "the others" are excluded from the postulated national space. In addition, the opposition between the Self and Other can be maintained or accentuated in nation-building processes, in which it serves two main purposes: (a) to construct the self-identity of the nation and (b) to provide reasons for its unsecured and marginalized status. Another starting point in the defining of the Other is the historical discourse analysis, where it is explained as a fiction about the foreign or "secondary construction of the foreign" (Münkler, Ladwig, 1998, 19). In this case the foreign is the one who is exiled and eliminated from one's own cultural circle in order to secure the space of national unity.

The intellectual elite of the $19^{\text {th }}$ century, the proponents of the national homogenization project in South-Eastern Europe, were conscious of the unstable situation in a polyglot community permeated by unequal relationships of power. Their texts therefore illustrate efforts to promote recognition in opposition to the regulative practice of the centre of Austrian-Hungarian Monarchy. In the last decades of the $19^{\text {th }}$ century the unification of Croat-inhabited territories was a main problem for Croatian nationalist movement that remained unresolved by the creation of the Dual Monarchy in 1867, since Regna tripartita Dalmatiae, Croatiae et Slavoniae after the Agreement in 1867 saw administrative division into Transleithania and Cisleithania, or the two halves of the Monarchy. The region's asymmetrical power relationships are marked by the dual peripheral position of Croats as subjects of both the Hungarian crown and the political centre of Vienna. The main political goals in that period were: linguistic unification, the modernization of the country with an underdeveloped agrarian economy and political independence and unification of territorially and administratively separate units. Due to the weakness of political elites, those goals were accomplished primarily through attempts to gain independence and establish cultural and educational institutions in its own language and understood as a process of national consolidation and modernization that challenged the existing imperial structures.

The approach of Miroslav Hroch postulates nations as historical constructs and outcomes of long-term integrational processes during which members of certain groups and inhabitants of certain territories gradually formed a unit. The transition to nationhood of a small, "oppressed" nation was more complex, because it had no native ruling class. In the Croatian case, the nation admittedly did form an ethnic and also a historical unit, but not a politically independent one. In Hroch's three-phase model, 
the second phase was crucial to the formation of small nations and it was marked by a shift from scholarly interest to active agitation for the national cause. Hroch emphasizes that nations are not homogeneous classes or social groups with the same interests as the proponents of national projects believed. What appears as "national interest" is, in Hroch's words, "the transformed and sublimated image of the material interests of concrete classes and groups, whose members took an active part in the national movement (or had to be won over to participate in it)" (Hroch, 1985, 185186). In discursive terms, however, this means that the Self of a nation is construed from the Other ex negativo, by excluding members of the dominant group as well as non-functional narratives and traditions. Aesthetic and performative engagement with nation-building against foreign rule in the Habsburg Monarchy was therefore exactly unable to overcome the lingering consciousness of deprivation, which partly stems from a deeply rooted understanding of one's own peripheral position, as well as the real, long-term existence of the Military Frontier, but it can represent the many facets of the border societies on the outer edges of the great empires.

As a consequence, this paper does not intend to analyse the concept of the border exclusively as a historiographical and social or empirical phenomenon, nor does it speak about "hard-fact geographical borders" (Kolstø, 2005, 22). Instead, it should be understood in its historical and cultural contexts of intertwined cultures marked by asymmetrical power relations. Such an understanding of the border as a cultural variable is an element for the cultural production of differences and shall be examined as the element of national myths in the framework of the national integration programmes of the $19^{\text {th }}$ and $20^{\text {th }}$ centuries found in the texts by two Croatian authors: August Šenoa and Miroslav Krleža. Šenoa's literary form is marked with the given political and social situation of his time to such an extent that it could be argued that it had a performative role in the political imagination, having in mind that Šenoa actively participated in constructing the leading idea of the emerging South Slav society. Two questions will be posed in this respect: Firstly, in what way the perception of the border is constituted in a fictional text, a novella by Šenoa from the $19^{\text {th }}$ century, and secondly, what are the implications of the mythologem of the border in Krleža's non-fictional texts from the $20^{\text {th }}$ century? As will be shown, there is a persistence in the understanding of the border as well as in the modification of the term, from Šenoa's attempt to create a new nation in accordance with ideas on the necessity of South Slav solidarity to Krleža's harsh critique of the idealized idea of antemurale Christianitatis. The goals of this analysis are as follows: 1) to point to the complex interpretations of the border mythologem, 2) to show that literary texts actively participate in nationbuilding processes, and 3) to elaborate upon the impossibility of their incorporation in binary models of identity politics. 
National integration narratives are usually in function of establishing borders, and their task is to separate the Self from the Other, yet the analysis of the selected fictional and non-fictional texts will indicate how they undermine binary oppositions engaged in construction of Otherness and Selfhood and, consequently, the understanding of the border as the line of demarcation. In these texts the borders are construed as an impossible endeavour separating the Self from the Other. Furthermore, this indicates that literary texts possess a function of mobilizing the nation, but they neither reflect nor support those nation-building processes powered by the strategy of exclusion. In this sense, borders are understood as identity boundaries that take a role in the establishment of mythopoetic structures mobilized in nation-building processes, but these roles are not unambiguous, and instead convey complex meanings and surpass national frameworks. In other words, the understanding of borders is linked to spatial and social phenomena, i.e. they are understood as "physical, literal structures of the state which also structure a range of meanings and belongings associated with a variety of identities" (Wilson, Donan, 1998, 25).

The thesis of the border as culturally produced and variable line of demarcation with the task to further reinforce the cohesive national identity and separate it from the other nations or governing imperial structures is applied on The Turks Are Coming, a novella by August Šenoa written in 1878, and the political essays by Miroslav Krleža in Ten Bloody Years [Deset krvavih godina] from the early $20^{\text {th }}$ century to demonstrate their impact on the perception of the reality in the context of the $19^{\text {th }}$ century national integration processes with aim to "mobilize formerly passive objects of history into citizens and subjects of history" (Smith, 1987, 156). It aims to show that those processes were not only in the hands of state authorities. Instead, they were also a product of political imagination in aesthetic portrayals and diverse forms of representations, corresponding to Benedict Anderson's thesis that identity politics - in this case, this means the lingering feeling of deprivation in the understanding of own border position - stretch "thin skin of a nation around the giant body of an empire" (Anderson, 1991, 79).

\section{The topos of border in a novella by August Šenoa}

The motif of Šenoa's novella The Turks Are Coming is a well-known "traditional topos of threat" (Lemberg, 2005, 27) found in the Croatian anti-Ottoman literature ${ }^{3}$ and characterized by strong antagonism between the Orient and the Occident. In that context, the Croatian side is understood as the antemurale Christianitatis (Kessler, 1981, 95), i.e. it is described as the last line of defence at the bulwark of western, Christian 
civilization while the Ottoman forces are, as a rule, demonized and depicted as a threat or danger to the occidental culture. However, at the time when the novella was written, due to political and military changes but mostly due to the weakening of the Ottoman Empire, that narrative powered by the need to express the feeling of endangerment at the border was radically reshaped because it had lost its potential for imperial mobilization, but could be used for the purpose of emerging national narratives in programmes of national homogenization. It can be even interpreted ironically, since "the old concept of the belligerent border region on both sides lost its foundation in reality" (Kolstø, 2005, 46). The age of wars-of-conquest and imminent threat was terminated but the topos of the Ottoman threat in many ways still formed identities, especially on the territory of the Military Frontier where Šenoa's novella takes place. Šnoa's story taken from the history of the Military Frontier was initially published in 1878, in five consecutive issues of Vienac zabavi i pouci, a literary magazine where Šnoa worked as the editor from 1874 to 1881. In this novella, Šenoa begins with two narratives; on the one hand, he focuses on the topos of the Military Frontier and on the other he constructs a new narrative for national integration and the necessary unity of people living on that political border, administratively separated from Croatian lands.

The German historian J. Osterhammel (Osterhammel, 2002, 386) presented a thesis about the polyethnic structure of the Empire throughout the $19^{\text {th }}$ century and its impact on the national states that emerged afterwards, which is another starting point for the analysis of the novella by Šenoa. It could be argued that Šenoa' novella works as a testimony about national processes inscribed in an imperial framework ${ }^{4}$ with the aim to perforate it and find performative strength to set a new national frame for one's own national South Slav or Croatian community. The polyethnic structure of the portrayed lands is a precondition and the basis of storytelling with the aim of creating a new national space. A specific imperial constellation thus becomes a precondition for reading Šenoa's novella, as a very simple story about love in which the representation of the Military Frontier as a geopolitical border takes multiple semantic roles. It is transformed from the historic line of demarcation into a point of contact between different cultures, and more in a strategic turnabout, the author also employs the border to imagine a future unification of the Triune Kingdom by converting the earlier administrative imperial border into national demarcations. The Military Frontier, earlier linked to the topos of the Ottoman threat, is now portrayed as a place devoid of initial meanings or a void space awaiting re-semantisation. Much more importance is given to the re-inscription of the border between the civil Croatia and the Military Frontier. This administrative border is precisely the border that

4 "If imperial institutions had shaped the structural particulars of mass nationalist associations, the budding consumer and advertising revolutions of the late nineteenth century also influenced many of the tactics with which nationalists experimented." (Judson, 2013, 129). 
Šenoa undertakes to annihilate in his novella dating back to the final phase of the Military Frontier, and he considered this border to be the main obstacle of national unification. In order to do so, the author is simultaneously combining transnational and transregional elements in his national-pedagogical programme that emphasizes the need for cohabitation and national unification on the territory that was split for a long time. The "overtly pedagogic function" (Judson, 2014, 73) is strongly expressed as a technique of mobilization of the fundamentally backward territory of the Military Frontier that had to be reintegrated.

In his letter to Ladislav Mrazović sent in 1877, Šenoa mentions "the original story titled The Turks Are Coming", noting that "the invasion of Bosnia", i.e. the disintegration of the Military Frontier was a fait accompli. In that context, he directly invites Mrazović to take part in political decisions: "As literary figures, we will have to roll up our sleeves - we have to be Croatian pioneers and build Croatian bridges over the Una and Sava rivers" (Šenoa, 1978a, 366). He is alluding to the fact that six decades of intensive warfare on the Ottoman border had serious economic and demographic consequences for the population on the Military Frontier, that had to be integrated into the Croatian-Slav lands. The very title of his "novella about the Military Frontier" (Frangeš, 1975, 240) links the imperial context of this area to the premise of national identification within the process of "retro-semantisation", as Hans Adler defines "subsequent meaning attributed to the notion of a nation" (Adler, $2000,39)$. In the light of the $19^{\text {th }}$ century historicism, the role of history is to establish collective beliefs, to which the homodiegetic narrator in The Turks Are Coming makes a direct reference: "I know that those old stories are like honey, you write them in your magazines and sell them to the world"5 (TI, 193-194). The historian of Eastern Europe, Klaus Zernack, notes that those "old stories" can be defined as the stories about the survival of "underprivileged and historical nations" (Zernack, 1994, 183) at the imperial crossroads of German, Slav and Ottoman cultures. According to Liah Greenfild, nationalism is an umbrella-term denoting "the related phenomena of national identity (or nationality) and consciousness, and collectives based on them nations" (Greenfeld, 1992, 3).

The story takes place on the territory of the Military Frontier at the time when it "had already become the object of political conflicts between Vienna, Pest and Zagreb" (Suppan, 1998, 241). At the same time, the title of the work is linked to ideologemes found in earlier Croatian short fiction which projected the conflict between hajduks and the Turks in literature. This very productive literary genre was functioning under the binary, anti-Ottoman ideological scheme (Nemec, 2000, 5-19). However, by the end of the $19^{\text {th }}$ century in The Turks Are Coming those binary, the anti-Ottoman

"Znam da idete na stare te priče kao na med, da ih prodate po vašim listovima svijetu." 
narratives are inscribed in an ironic way, because the supposed acute threat from the Turkish attack turns out to be non-existent, or, rather, a void space around which the narrative develops. With the weakening of Ottoman power, the Military Frontier lost its function as well as long-nurtured awareness about its role as the bulwark of Christianity. Thus, the Ottoman forces never really appear in the novella, that is, they are actualized only in the form of a radical annihilation, and in dialogues, they are even dehumanized": "If the Turks were human, they could have pointed their cannon to take away a chicken from your plate; that is how nice the hills across from the Cetina River are positioned" (TI, 196). Here, we see the central elements of fiction about the foreign or "a secondary construction of the foreign" (Münkler, Ladwig, $1998,19)$, as the one who is exiled and eliminated from one's own culture circle - in this case the Turks. In Eric J. Hobsbawm's conception of nationalism, the Othering as a discursive phenomenon also illustrates the Janus-faced and multi-faceted character of nationalism (Hobsbawm, 1992).

The imminent threat is much more related to the rift between the Kingdom of Croatia-Slavonia-Dalmatia and the Military Frontier at the time of demilitarization and the strengthening of disintegration processes than to the Ottoman military forces and "the Turks" - one's own territory had to be established and protected during a long-lasting war fought between spatially close entities that struggled for control of their zones of influence. In that context, national mobilization plays a crucial role and in literary texts leads to the utilitarian function or a form of national pedagogy. The elements of national homogenizing programmes with the aim of raising an emerging nation are transposed into the story about the final stage of life of frontiersmen in the Slunj area and the history of the territory around Slunj and Karlovac. The novella is based on the performative aspect of national unity that is apparent in many points that coincide with the conversational, oral communication characterized by a confidential, almost intimate tone. This conversational tone is particularly evident at the beginning and end of the story when the narrator communicates directly with the reader. The narrator of the story is omniscient - he tells a true story and thus claims authentication of what is told, at the same time eliminating the distance between him and the reader who is invited to take an active part. This also implies the elimination of the dividing line between the text and life practice by way of using the "rhetoric of nation" (Judson, 2014, 62) in the novella. The storytelling, therefore, does not only develop the story but also establishes the relation with the reader, who represents the projected national figure. The literary text offers opportunities to engage in nation-building activities in the public space, just as, as Pieter Judson puts it, the nationalizing elites "sought to

6 "Da su Turci ljudi, mogli su vam iz topa višnjevca iztepsti pile iz tanjura, tako sgodno im stoje bregovi nasuproti Cetinu." - In Šenoa’s novella titled "The Cannon of Turopolje" the threat from "the Turks" is also mentioned, and the Turks are even called "dog-heads" ("pasoglavci"; Šenoa, 1978b, 120). 
build loyalty to national communities on the borderlands by literally nationalizing every possible aspect of daily life" (Judson, 2013, 131).

In the brief introduction, the intradiegetic-homodiegetic narrator gives an account of the sale of the formerly much admired fortress of Cetin: "The famous Cetin, where our great-grandfathers elected Ferdinand of Habsburg to be their king, was sold two days ago at an auction"7 (TI, 193). This observation is a direct reference to the termination of medieval Croatian sovereignty and the agreement signed with the Habsburgs together with the establishment of the Habsburg Military Frontier in 1522 (Suppan, 1998, 13). In story within a story the homodiegetic narrator, Captain Vukić, recounts a tale about the time when he served as a so-called "black frontiersman" in the Slunj regiment of the Karlovac generalcy. The plot thus moves back to the first half of the $19^{\text {th }}$ century, or the time of the Illyrian movement, since captain Vukić gives an account of his adventures as a fierce Illyrian, known as "Andro the TambourinePlayer" (TI, 194). By doing so, he sheds light on the Illyrian programme, the main objective of which was to construct a linguistic and cultural community in line with the conceptions founded in the class framework of the Croatian political tradition (Kessler, 1981, 91). The national movement was to a very large degree defined by the rather broad scope of the Illyrian movement, which advocated South Slavic solidarity with the hope of achieving fundamental Croatian political aims. Subsequently, there were two major causes: a Croatian national cause aimed primarily at the unification and independence of the people of Croatia and pan-South Slavic unity, and the Yugoslav cause also oriented towards the integration of the neighbouring South Slavic nations, articulating the desires for the unification of South Slavic nationhood and the principles of nationality and democracy in a politically still undefined unification programmes.

Andro the Tambourine-Player, in the role of people's tribune, criticizes the current "cursed disagreement between the Šokci and the Vlachs" (TI, 194) and emphasizes the Illyrian emancipatory and integrative idea of pan-Slavic unity (Karaman, 2000, 90-110) together with the principle of integration of various South Slavic nations with many regional, religious, social and ethnic differences. This also links Šenoa's novella with ideas of the politician, Roman Catholic bishop and benefactor Josip Juraj Strossmayer (1815-1905), as the path towards "the real unification of segregated people" (Šenoa, 1978a, 217). Andro criticizes hegemonic rule and Germanization aspirations when he mentions the strict "Regimentssprache" (TI, 195) and banning of the Illyrian name in 1843. After that, his colonel (obrstar) says that the Illyrian ideas are "Schwindelei" (ibid.; in italic and German in the original text). This is to recall the strict imperial

$7 \quad$ "Slavni Cetin, gdje su naši pradjedovi izabrali Ferdinanda Habsburgovca za kralja, prodan je prije dva dana na javnoj dražbi." 
borderlines, which did not allow any national determination: "According to him, we were not Croatians, nor Illyrians, nor Slavs but 'kaiserliche königliche Grenzer"' (TI, 194). This fixes upon the long-held understanding of a peripheral position as well as the perception of oppression and the need to establish a Croatian, Illyrian or Slavic identity independent from the imperial, unifying narrative.

The experience of deprivation on the border appears at the beginning of the story and has a clear appellative function in relation to the present. However, the threat of the Turkish attack takes shape only in Andro's reminiscences about the attack on the fortress of Cetin one hundred years before when "the Turks" killed an officer, a story which captain Müller, represented almost as a caricature, repeats every single day: "Be especially careful around the place where the Turks killed our officer from an ambush one hundred years ago"' (TI, 197). After that, Andro gives an ironic remark saying that he had heard the story at least forty-five times. Despite his last name, Captain Müller is not "a Szwab", but "the son of a frontier officer" (TI, 196), profoundly committed to his historic mission to defend the border and imperial power, yet portrayed as a relic of past times, unable to adapt to the new circumstances. He is the laughingstock of the whole regiment when he threatens: "Mujo would remember who Major Müller was"9 (TI, 197). Having in mind that this simple phrase reappears many times, it is striking that both names are foreign and could be laughed at from the position of a homogeneous national identity.

Thus, the former mythologized "mission to defend the border" (Kaser, 1997, 223) serves only as the background of a simple love intrigue. The central love story between figures from the middle class has a very clear pedagogical task to communicate a new concept of love, while still showing the individual power of the bourgeois class to make decisions and control their own destiny. One figure in the novella, Mladen Novak, a Catholic military doctor and Croat from Zagorje, falls in love at first sight with Manda, the daughter of the Orthodox priest Gligorije, and that love emphasizes the togetherness of Catholic and Orthodox people on the territory of the Military Frontier, or in recent scholarly texts the so-called Triplex confinum (Roksandić, Štefanec, 2000), in the midst of discussions about the incorporation of this territory, and can be understood as an attempt to create new social boundaries in Military Frontier communities. The border is not an element of separation, but of assimilation to the new, as yet unsecured national entity. The false attack on the fortress and the resolution of the love intrigue was staged by Wolf Heim, "a corporal of Jewish descent from Galicia” (TI, 235). A clear division line or a strict border between Christian and Muslim inhabitants in this intrigue becomes relativized and portrayed as in fact porous, i.e. although the enemy

8 “Osobito pazite na ono mjesto gdje su Turci prije sto godina ubili našeg časnika iz zasjede."

9 “Zapamtio bi si Mujo što je major Müller." 
remains invisible, in a clever deception staged to prevent an unwanted marriage, Wolf Heim's role is undertaken by local peasants who pretend to fight a battle in order to smuggle Manda inside of the fortress and win a bet, after which she would no longer have to marry the old Major Radulović.

In a way, the homodiegetic narrator becomes the author's voice propagating ideas pertaining to the new époque, such as "brotherhood" (TI, 242) between the Catholics and the Orthodox community, as well as the need for solidarity and national spirit ("nationality"; TI, 194) on the border, ideas which can be traced back to the Illyrian times. By doing so, he actualizes two processes, i.e. the erosion of the imperial order of the Military Frontier on the one hand, and national aspirations on the other, especially in the light of the organic convergence of the semi-autonomous Kingdom of CroatiaSlavonia-Dalmatia. The text emphasizes the concept of coexistence in order to introduce the image of a "solidary community" in the Military Frontier as a place of growing national and imperial political confrontations (Clewig, 2005, 232). The intradiegetic narrator dismisses objections to the marriage between the Catholic medical doctor and Orthodox Manda as "old prejudice" (TI, 228) in order to introduce contemporary political discourse and confirm "the transformation of the comprehensive administrative, political and public (primarily cultural) life in the spirit of civil libertarianism" (Karaman, 2000,38 ). It is clear that the narrator refers to the existing cultural pluralism on the imperial territory to extrapolate the national ideals of freedom and self-determination of the bourgeois class. Šenoa's novella clearly takes part in building local national society with "the kind of prestige that nationalist writers claimed for their cultures" (Judson, 2014, 78). The problematic status of the border is however inscribed into narration by excluding the Other, in this case the Ottoman Empire.

\section{Krleža's essays on antemurale-mythos as a border phenomenon}

Several decades later, Krleža’s perception of Šenoa departs from the inspection of the utilitarian, patriotic-pedagogical and homogenizing function of his "national short prose fiction" (Barac, 1926, 18). Stanko Lasić introduces his thesis on "Šenoa's didactic ideologism" with the intention "to establish harmonic synthesis by unifying three entities: literature, nation and Catholic morality" (Lasić, 1970, 19). With this remark presented in a discussion on Confrontation on the Literary Left, Lasić perceives Šenoa's work as "the most significant attempt of Croatian petit-bourgeois consciousness" and a turning point after which all "further structures in the Croatian literature are determined in their relation to Šenoa as a kind of purity (structure-type) that is either accepted in its variations or entirely negated" (ibid., 19). Krleža also writes about the 
"age of petit bourgeoisie integrations" and "quasi-advanced legend"10 (Krleža, 1957, 488) of the early Yugoslav concept. It could be argued that Krleža's mode of ironic negation actually varies and negates Šenoa's intentions at the same time. If Šenoa was a secular intellectual and represented "the new stratum of intelligentsia which formed the channel for disseminating the new ideals of rational planning and social education" (Smith, 1987, 160), Krleža first reflects, and after WWII actually redefines, the community by applying an ideological key.

Miroslav Krleža is one of the most prominent Croatian authors of the $20^{\text {th }}$ century and one of "the most passionate critics of the Habsburg" (Gauß, 1988, 16). In his early essays, Miroslav Krleža links the border phenomenon to the concept of antemurale Christianitatis and perception of the Kingdom of Croatia, Slavonia and Dalmatia on the borderline of the Austro-Hungarian Monarchy. It is interesting to note the directional motif of the border that reappears in Krleža's texts, which proves the persistence of border awareness even in the $20^{\text {th }}$ century: "This is the inertia of the Austrian Eastern Mark, of the Military Border, Viennese waltzes, Austro-Hungarian monarchy and West European prejudice, which wants to isolate the western South Slav lands from the 'Balkan Gypsies"' (Krleža, 1957, 480). ${ }^{11}$ His early political essays collected in a book Ten Bloody Years find grounds in the myth about a small European nation on the periphery also facing a strong anti-Habsburg emphasis.

They did not call only us 'antemurale Christianitatis', but all the other Catholic national miserables on the Danube and on the Visla that died on the bloodsoaked vanguard of European interests, while the centres of those civilisations banqueted $[\ldots]^{12}($ Krleža, 1957, 120).

From a post-imperial perspective, South Slav areas of the Habsburg Empire are usually somewhat restrictively labelled as semi-, quasi- or even pseudo-colonies in the broader context of 'internal colonialism'. Special attention will be paid to the constellation of centre and periphery, i.e. to the marginal position of the border. According to Anthony D. Smith, the feeling of deprivation as a consequence of a semicolonial constellation is used by ethnic nationalist to bolster the autonomist case, by pointing to such consequences as governmental neglect, central exploitation of the periphery's resources, unequal and one-sided exchanges of goods, the emigration of

10 "U eri malograđanskih integracija osamdesetih godina Jugoslavenstvo kod nas [...] stvorilo je quasinaprednu legendu o bogatoj kulturnoj prošlosti naših naroda, [...]”.

11 “To je inercija austrijske Istočne Marke, Vojne Granice, bečkih valcera, austro-ugarske monarhije, zapadnoevropskih predrasuda, koja po planu izoluje zapadne južnoslovjenske zemlje od 'balkanskih cigana”.

12 “Da smo 'Predziđe Kršćanstva', to nisu govorili samo nama, nego svim ovim bijedama od stradalnika na Dunavu i na Visli, koji su ginuli na krvavim predstražama, dok se u centru civilizacije bančilo [...] Da smo krvarili na braniku civilizacije (zapadnoevropske), u bitkama za inostrane kraljeve "do posljednje kapi krvi”, o tome je pisala centralnoevropska štampa sve do sloma Austrije [...]”. 
valuable skills and manpower, transport and communication systems that favour the centre, one-sided trading patterns, unequal allocation of services, including education, and the growth of a stratification system in which ethnic minorities tend to occupy lower-status roles. (Smith, 1987, 163)

Krleža denounces national myths by referring to the past and long-established rule of the Habsburgs, but holds onto the narrative of deprivation. By doing so, Krleža to a certain extent supports the theses about "misery of small eastern European states" (Bibó, 1995, 11-93), later on formulated by famous Hungarian historian István Bibó, at the time when modern nations were formed. Because of the long and unfinished nation-building process, the tight link between democracy and nationalism did not appear since inside of the Habsburg Monarchy the nation was formed as "a decisive precursor of national differential autonomy (Volk)" (ibid., 21) within the concept of linguistic nationalism where "linguistic unity became a political and historical factor; above all, a factor of territorial demarcation within the existing boundaries" (ibid., 23). For that reason, he interprets developmental obstacles as "the immediate consequence of the afflicted historical traumas" (ibid., 43). Following Bibós thesis, the main characteristic of the small states at the European periphery is "the existential anxiety about the community" (ibid.). By addressing the historical trauma of marginalization Krleža reinscribes the myth of martial sacrifice for the West on the border of civilisations as a situation of the oppression of the small nations.

In his early essays he seeks to answer questions regarding the alarming situation in the final phase of the " $k$. und k.", imperial and royal Austrian-Hungarian dual monarchy, questions raised by Miroslav Krleža in his autobiography, where he reiterates the position of marginality by posing the question: "Where are those distant Slav countries; who would be upset about the Balkans, about those unknown barbaric peoples?" (Krleža, 1972, 583) ${ }^{13}$ His question highlights the vagueness of the boundary between the Self and the Other, a vagueness inherent to unfinished attempts of nation-building and a form of "internal colonialism" (Smith, 1987, 163). One of the results of this vagueness is the opening up of a discursive space in the field of literature and experience, a field exemplified by Krleža’s non-fictional texts, which reconstruct the now historical world of the final phase of the monarchy. On the one hand, Krleža's essays draw conclusions that are typical of the entire Habsburg era by construing a paradoxical narrative combining the comprehensive negation of the recent past with a future-oriented 'optimal projection' of Marxist and materialistic provenance. On the other hand, the post-imperial perspective draws attention to strategies of the production and imagination of cultural narratives, and also to the

13 "Gdje su te daleke slavenske zemlje, tko bi se uzrujavao za Balkan, za ove nepoznate barbarske narode?" 
ways in which literature acts a model of reality and representing the ideological identity space.

In this particular case, literature moreover assumes an active part in the construction of reality with respect to the experience of social marginality of "the subaltern bureaucrat"14 (Krleža, 1972, 422), as Krleža describes the typical " $k$. und k." mentality. The effect of essentialist binary oppositions (such as colonial master and subject or centre and periphery) develop a hybrid character during the "days of the Austrian Military Border" (Krleža, 1957, 139) ${ }^{15}$ in "a world that for centuries has waged as one and the unique Border under the imperial barracks"16 (Krleža, 1957, 194). Krleža addresses the problem of borders within the Habsburg Empire in his essay entitled Iza kulisa godine 1918 [Behind the Scenes of the Year 1918] (Krleža, 1972, 135), as well as in some of his other, earlier works of non-fiction. For example, in the travelogue Izlet u Rusiju 1925 [A Fieldtrip to Russia in 1925], where he examines the question of historical pessimism from the position of the European periphery, which exists as "the remainder of the remains" (reliquie reliquiarum) in the "Asiatic chaos" on the "Ottoman border" (Krleža, 1960, 29). He goes on to remark that since the time of the Ottoman domination of the Balkans, the "relations have remained equally inhuman, cruel and un-European" (ibid.).

By looking at the circumstances in the Habsburg Monarchy from the vantage point of Krleža's work we can avoid reducing the South Slav periphery to the position of backwardness. Instead, the periphery can be observed as a variety of the 'antemurale Christianitatis' myth - a myth integral to the frontier Orientalism which refers to the specific position of the South Slav periphery during the time of the Ottoman threat to the Habsburg Monarchy, when Slavonia was the demarcation line between the Ottoman and Habsburg empires. Krleža refers to the specific role of this myth in the process of the nation's identity formation, when it functioned as an ideological narrative about the South Slav understanding of the Military Frontier as a "defence wall of Christianity [against Islam]". The Military Frontier is in this case a historical and political fact, but also has the character of a national myth. In his gloomy apocalyptical diagnosis Krleža describes this condition as follows:

Our people that received charity from foreign hands at foreign doors and from foreign tables, cursed by death under its own roof, going hungry and barefoot for centuries, like an animal sheared and skinned by foreign masters, was well aware that without your own nation, you are no-one. And all of us, who hated our own nation and never cared for it, unhappy with our shack,

14 “[S]ubalternog birokrate".

15 “[A] ustrograničarskih dana”.

16 “...] svijet koji je vjekovima ratovao kao jedna i jedinstvena Granica pod carskim barjacima." 
in which we were bitten by our own fleas, all of us dreamt of the superb food waiting for us in the promised lands of Western Europe. ${ }^{17}$ (Krleža, 1963, 135)

This highlights the arguably traumatic position of the insecure national identity within still unstable internal cultural borders. In one of his early materialist and pacifist reflections Krleža assumes that modern European history can be divided into two parallel historical narratives: the narrative of "the drunk and pagan patricians, these Cezars and Cezaromaniacs" on the one hand, and the "history of the Pannonian slave" (Krleža, 1972, 16) ${ }^{18}$ on the other, which can be understood as a symbolic border of European centres and South Slavic periphery. This is a new facet in the understanding of border - the persistent awareness of being on the border produces the status of exclusion from the West or the European realm. In the South Slav region the process of nation-building has its source in the collectively shared consciousness of being a part of the European cultural realm and the simultaneous awareness of being in a marginalized position (Biti, 2016). The complexity of these processes in the realm of symbolic geography was illustrated by Ivo Žanić, who emphasized "the dynamic interplay, co-existence or polemical concurrence of the three central metaphors: Croatia as bulwark (antemurale) of Christianity / Roman Catholicism / civilization / Europe; Croatia as crossroads of East and West, North and South; Croatia as bridge between Western and Eastern Christianity, the West and the Balkans, Slavic and Romance nations" (Žanić, 2005, 76). This deep ambivalence is the defining feature of conflicting historical narratives functioning as the basis of the nation's identity policy. These relations undergo a process of doubling by distinguishing between 'Europe' and the 'Balkans':

Here is a botanical garden with alpine flora, here a greenhouse with tropical plants, here Chinese pavilions overlooking an artificial pond with swans, here a library of bronze and marble with hundreds of thousands of volumes, and a hundred metres away from this library there is stagnation, Asia, a dull province, a backward and worthless land of peasants, just the same as a hundred years ago, when our capital city was, along with all other SouthSlav towns, a pitiful backwater town, forgotten somewhere far away, God only knows where, on the Turkish border [... $]^{19}$ (Krleža, 1972, 125).

17 "Naš narod, koji je kod tuđih ognjeva i tuđih trpeza primao milostinju iz tuđe ruke, s teškim prokletstvom pogibije pod svojim vlastitim krovom, gladan i bos vjekovima, kao govedo, koje su tuđa vlastela strigla i odirala, dobro je znao, kad je spoznao, da nikoga nema, tko svoga nema. A svi mi, koji smo svoje mrzili i svoje nikada čuvali nismo, nezadovoljni kolibom svojom, u kojoj su nas vlastite uši grizle, svi smo mi sanjali o vrhunaravnom pirinču obećanih zapadnoevropskih zemalja."

18 "[P] $]$ ijanih i poganih Patricija, ovih Cezara i Cezaromana"; "historija panonskog roba".

19 "Tu botanički vrt s alpinskom florom, tu staklenici sa tropskim biljem, tu kineske gloriete nad umjetnim jezercem i labudovima, tu biblioteka sva u bronzi i u mramoru s nekoliko stotina hiljada svezaka, a stotinu metara od te biblioteke: žabokrečina, Azija i najbanalnija provincija zaostale i bijedne seljačke zemlje, kao prije stotinu godine, kada je naš glavni grad sa svim ostalim južno- 
In this way Krleža establishes the idea of an indefinable border space between the East and West, and it is at the same time attached to the constellation of centre and periphery, which implies a relationship of tension between modernity and backwardness. The actual asymmetry in the cultural and social development of centres and peripheries also implies the existence of potentially imperialistic forms of rule and domination and the implicit long-term repercussions of belated nation-building. It is, however, necessary to acknowledge the fact that the centre and its periphery are interconnected in a relational way. By producing one's own Other as the ex-centric, incomprehensible, marginal or inarticulate Other, which is nevertheless one's own Other, one consolidates and strengthens one's own wavering position of authority as the centre. As a result the periphery remains dependent on the centre, characterized by negative economic, cultural and social features. The idea of national consolidation is interpreted as an act of desperate defence against pressure for assimilation coming from Vienna, but even more intensely from Budapest.

Krleža believes the processes of modernization are inseparable from the constant feeling of national, social and political inferiority deeply rooted in the perception of the self. Paradoxically, the processes of modernization thus go hand in hand with the reproduction and strengthening of a deeply rooted and therefore indestructible and repetitive marginal position. This nineteenth-century self-perception, which signals a case of borderline consciousness but also petrifies itself as a narrative of deprivation, is double-coded: on the one hand, it is conditioned by the latent discourse of Orientalism, in which one's own civilized status arises from the dissociation of the self from the Other. On the other hand, it ties in with explicit and desirable Occidentalism. The fact that the South Slavs in the monarchy were considered "one's own Other" and the "Barbarians" 20 confirms this complex double-coding. In spite of the fact that affiliation with the Occident was proclaimed as the goal, this goal was in itself split and divided, producing incessant feelings of inferiority, the danger of assimilation and the fear of subjugation.

Thus, this view becomes transformed in Krleža's post-World War II essays. The concept of the Illyrium or the territory that is a function of the true "frontier", perceived as "European shatter-belt", is treated in Krleža's essay Illiricum sacrum. Fragments from 1944 published in 1963 in the literary magazine Kolo. Confronted with destruction of the city of Zadar and violence during "one thousand years of war" (Krleža, 1966,

slovjenskim gradovima bio sažaljenja dostojna palanka, zaboravljena negdje daleko na turskoj granici, za božjim leđima..."

20 In his history of the nineteenth century Jürgen Osterhammel picks out as a central theme the features of empires and their "inner" colonies and concludes that the entire Habsburg Empire was "geographically as well as culturally a European-Occidental multi-ethnic structure" (Osterhammel, 2007, 626). 
11) at the South Slav periphery, Krleža develops a cultural and historical sketch of a different area by way of applying "affective rhetoric" (Žmegač, 1986, 26) typical for his style. In that essay Krleža claims that "we served to the Byzantine Empire, and Vatican, and Venice and Vienna as Antemurale for centuries, until the moment of their collapse" (Krleža, 1966, 32). However, at this time he replaces the narrative of deprivation with a utopian perspective about the unity of South Slav, i.e., Yugoslav nations. In this respect, the myth of antemurale Christianitatis once again brings the petrified awareness of the border position to the fore, but reinscribes it by turning it to the centre of a new, South Slav culture. In the essay, Krleža talks about "our people" and the identification with the people living in the South Slav lands. The very title of the essay refers to the long-established perception of the South Slavs as direct descendants of the Illyrian population. Krleža calls into question this misconception by developing a vision about the new cultural and historical community on that territory by emphasizing the principle of acculturalization and the synthesis of old and new elements back to the times of "barbaric tribes" as a "poorly identified amalgam submerged in a fantastic dissolution of Roman and Hellenic decadent tradition, in a magical mixture of eastern barbaric inceptions and phantasmagorias" (Krleža, $1966,14)$ bearing a unique signature of "our typical, South-Slavic, non-conformist will" (ibid.). This new semantisation of the border is understood as a project aiming towards the future and prompted by the idea about the independence of the SouthSlavs that emerges distant from the East and the West at "East-European Limes" (Krleža, 1966, 28), only to be established as a supranational Yugoslav politic founded on the new ideological grounds following the end of the World War II. The peripheral territory of the European border grows into a vision of the Illyricum as an amalgam of cultural practices, discursive traces and images about the future, while intending to realize a new synthesis on the territory of Yugoslav "cultural and geographic zone" (Hösch, 2004, 398) as a new social construct and cultural space. Krleža's homogenizing narrative together with the work of the historian Hans Lemberg may be understood as an unfinished, utopian project of a supranational body politic. Krleža's finds his point of departure in the constitutive plurality of ethnic and cultural borders. In his essay, he offers the possibility of polycentric narratives about the border as the place of amalgamation rather than demarcation.

\section{Conclusion}

The border in literary texts "must be recognized if negotiations involving nations, hybrid identities and cultural liberation are to acknowledge not simply the celebratory potential of the contact zone, but also the ineradicable trappings of power that patrol the boundaries of any culture." (Castronovo, 1997, 203). The representations of the 
border in literature point to the problem of political and cultural identity and the impact of nation-building processes in South-East Europe in the Triune Kingdom as an underdeveloped and rural land. The mobilizing discourses were very much present in the Croatian literature of $19^{\text {th }}$ century and were reinterpreted by the Croatian author Miroslav Krleža at the beginning of $20^{\text {th }}$ century. In the case of the Croatian lands, one can observe a multitude of ways in which local identities were expressed throughout the $19^{\text {th }}$ and at the beginning of the $20^{\text {th }}$ centuries - locally, ethnically, linguistically, and or religiously, as a borderland on the crossroads of the Habsburg and Ottoman Empires. Following the representation of the border, one can follow the change from the imperial to national or supranational communities and the moments in which the "power had shifted to the peripheries of the empire, to new nationalist political forces in the new power centres of Prague, Cracow, Zagreb, and Lvov which were pulling away from the centre, i.e., Vienna and the Habsburg hereditary lands" (Wank, 1997, 52).

At the same time, in literary texts of August Šenoa and Miroslav Krleža the "myth of ethnic origins and descent" (Smith, 1987, 192) was very much present. In his novella on the Triplex Confinium Šenoa depicts the moment of "historical transition in the nature of the 'State' from a monarchical, dynastic body politic and its subjects to a 'State' (read: nation/nation-state) in which the subjects become citizens, and thus became loosely tied to the direct control of a centralized lawlike apparatus" (Lugo, 1997, 49). Šenoa's literary myth can be defined as a myth of rebirth and restoring the lost community space in the Triune Kingdom, whereby Krleža is using a myth of origins in space (Smith, 1987), i.e. he is postulating a new, supranational Yugoslav community in his essay Illyricum sacrum as an act of resistance towards the West and the imperial history of the " $k$. und k." monarchy, in which stories about the survival of "underprivileged and historical nations" (Zernack, 1994, 183) were supplanted by the projection of a new, South Slav cultural centre. In opposition to that, in his earlier essays Krleža refers to the myth of the border as an element of a semi-colonial selfconsciousness to be overcome.

Departing from the thesis that literary texts, in addition to their capacity to provide description, also demonstrate the potential for construing reality, this paper focuses on the selected narratives, or essayistic and poetological texts written by the canonical Croatian authors August Šenoa and Miroslav Krleža, and demonstrates the literary representation of various border phenomena in the Austro-Hungarian Empire (Šenoa) and their gradual change in the post-imperial age following the Great War (Krleža). If in cultural geography a text is understood as a culture-specific code for space, here we see how the perception of the border influences the discursive processes of nation-building. By challenging the imperial narrative about the Military Frontier, the image of the Ottomans in the late $19^{\text {th }}$ and early $20^{\text {th }}$ centuries as well as the associated 
national and homogenizing discourses, the article analyses a number of variations in the understanding of the border as the result of a discursive process in different epochs as phenomena that have acquired multiple and complex meanings as process, place and mythologem. The analyses of fictional texts by Šenoa and non-fictional ones by Krleža show the ideological and discursive implications of nation-building processes in the post-imperial era with special regard to the thesis that borders are construed as impossible endeavours aiming to separate the Self from the Other in projects of national (Šenoa) or later supranational homogenization (Krleža).

\section{References}

Adler, H., Nation. Johann Gottfried Herders Umgang mit Konzept und Begriff, in: Unerledigte Geschichten. Der literarische Umgang mit Nationalität und Internationalität (ed. Essen, G.,Turk, H.), Göttingen 2000, pp. 39-55.

Anderson, B., Imagined Communities. Reflections on the origin and spread of nationalism, London, New York 1991.

Bakhtin, M. M., The Dialogic Imagination. Four Essays (transl. Emerson, C., Holquist, M.), Texas 1981.

Barac, A., August Šenoa, Zagreb 1926.

Bibó, I., Bijeda istočnoevropskih malih država, in: Regije evropske povijesti (ed. Bibo, I., Huszar, T., Stucks, J.), Zagreb 1995, pp. 11-93.

Biti, V., Miroslav Krleža und die kroatische Enteigungsgeschichte, in: Wiener Slawisches Almanach 77, 2016, pp. 31-96.

Castronovo, R., Compromised Narratives along the Border: The Mason-Dixon Line, Resistance and Hegemony, in: Border Theory. The limits of cultural politics (eds. Michaelsen, S., Johnson, D. E.), Minneapolis 1997, pp. 195-220.

Clewig, K., Der begrenzte Wert strategischen Wertes. Dalmatien als habsburgische Randprovinz, in: Grenzregionen der Habsburgermonarchie im 18. und 19. Jahrhundert. Ihre Bedeutung und Funktion aus der Perspektive Wiens (ed. Maner, H.-C.), Münster 2005, pp. 217-234.

Crang, M., Cultural Geography, London 1998.

Dukić, D., Sultanova djeca. Predodžbe Turaka u hrvatskoj književnosti ranog novovjekovlja, Zadar 2004.

Frangeš, I., Realizam, in: Povijest hrvatske književnosti 4. Ilirizam, realizam (eds. Frangeš, I., Živančević, M.), Zagreb 1975.

Gauß., K.- M., Tinte ist bitter. Literarische Porträts aus Barbaropa, Klagenfurt, Salzburg 1988. 
Gingrich, A., Orientalismus, in: Habsburg neu denken. Vielfalt und Ambivalenz in Zentraleuropa. 30 kulturwissenschaftliche Stichworte (eds. Feichtinger, J., Uhl, H.), Vienna, Cologne, Weimar 2016, pp. 157-162.

Greenfeld, L., Nationalism. Five roads to modernity, Harvard 1992.

Goldstein, I., The Boundary on the Drina, in: Myths and Boundaries in South-Eastern Europe (ed. Kolstø, P.), London 2005, pp. 77-106.

Hobsbawm, E. J., Nations and nationalism since 1780, London 1992.

Hösch, E., Kulturgeographische Zonen, in: Lexikon zur Geschichte Südosteuropas (eds. Hösch, E., Nehring, K., Sundhaussen, H.), Vienna, Cologne, Weimar 2004, pp. 398-400.

Hroch, M., Language and National Identity, in: Becoming National: A Reader (eds. Grigor, R., Suny, G. E.), New York, Oxford 1996, pp. 65-76.

Hroch, M., Social preconditions of national revival in Europe, Cambridge, 1985.

Judson, P. M., Marking National Space on The Habsburg Austrian Borderlands. 1880-1918, in: Shatterzone of Empires. Coexistence and Violence in the German, Habsburg, Russian and Ottoman Borderlands (eds. Bartov, O., Weitz, E. D.), Bloomington, Indianapolis 2013, pp. 122-135.

Judson, P. M., Do Multiple Languages Mean a Multicultural Society? Nationalist "Frontiers" in Rural Austria, 1880-1918, in: Understanding Multiculturalism. The Habsburg Central European Experience (eds. Feichtinger J., Cohen, G. B.), New York, Oxford 2014, pp. 61-82.

Karaman, I., Hrvatska na pragu modernizacije. 1750-1918, Zagreb 2000.

Kessler, W., Politik, Kultur und Gesellschaft in Kroatien und Slawonien in der ersten Hälfte des 19. Jahrhunderts. Historiographie und Grundlagen, Munich 1981.

Kolstø, P., Introduction: Assessing the Role of Historical Myths in Modern Society, in: Myths and Boundaries in South-Eastern Europe (ed. Kolstø, P.), London 2005, pp. $1-35$.

Krleža, M., Illyricum sacrum. Odlomci rukopisa iza kasne jeseni 1944, in: Kolo. Časopis Matice hrvatske za književnost, umjetnost i kulturu 7 (1963), pp. 149-187.

Krleža, M., Književnost danas, in: Eseji III (Sabrana djela Miroslava Krleže, 20), Zagreb 1963, pp. 97-139.

Krleža, M., O malograđanskoj ljubavi spram hrvatstva, in: Deset krvavih godina i drugi politički eseji (Sabrana djela Miroslava Krleže, 14/15), Zagreb 1957, pp. 119-153.

Krleža M., Nekoliko riječi o malograđanskom historizmu uopće, in: Deset krvavih godina i drugi politički eseji (Sabrana djela Miroslava Krleže, 14/15), Zagreb 1957, pp. 97-153. 
Krleža, M., Teze za jednu diskusiju iz godine 1935, in: Deset krvavih godina i drugi politički eseji (Sabrana djela Miroslava Krleže, 14/15), Zagreb 1957, pp. 473592.

Krleža, M., Djetinjstvo 1902-03 i drugi zapisi (Sabrana djela Miroslava Krleže, 27), Zagreb 1972, pp. 581-587.

Lasić, S., Sukob na književnoj ljevici 1928-1952, Zagreb 1970.

Lemberg, H., Imperien und ihre Grenzregionen im Europa des 18. und 19. Jahrhunderts. Einige einführende Beobachtungen, in: Grenzregionen der Habsburgermonarchie im 18. und 19. Jahrhundert. Ihre Bedeutung und Funktion aus der Perspektive Wiens (ed. Maner. H.-C.), Münster 2005, pp. 25-36.

Lemberg, H., Unvollendete Versuche nationaler Identitätsbildungen im 20. Jahrhundert im östlichen Europa: die "Tschechoslowaken", die "Jugoslawen", das "Sowjetvolk", in: Nationales Bewußtsein und kollektive Identität. Studien zur Entwicklung des kollektiven Bewußtseins in der Neuzeit (ed. Berding, H.), Frankfurt a. M. 1994, pp. 591-607.

Lotman, M. Y., Universe of the Mind. A Semiotic Theory of Culture, London, New York 2001.

Lugo, A., Reflections on Border Theory, Culture, and Nation, in: Border Theory. The Limits of Cultural Politics (eds. Michaelsen, S., Johnson, D. E.), Minneapolis 1997, pp. 43-67.

Münkler, H., Ladwig, B., Einleitung. Das Verschwinden des Fremden und die Pluralisierung der Fremdheit, in: Die Herausforderung durch das Fremde (ed. Münkler, H.), Berlin 1998, pp. 11-27.

Nemec, K., Poetika hajdučko-turske novelistike, in: Nemec, K., Mogućnosti tumačenja, Zagreb 2000, pp. 5-19.

Osterhammel, J., Expansion und Imperium, in: Historische Anstöße: Festschrift für Wolfgang Reinhard (ed. Burschel, P.), Berlin 2002, pp. 371-392.

Osterhammel, J., Die Verwandlung der Welt. Eine Geschichte des 19. Jahrhunderts, Munich 2007.

Rieber, A. J., Triplex Confinium in Comparative Context, in: Constructing Border Societies on the Triplex Confinium (ed. Roksandić, D.), Zagreb 2000, pp. 13-28.

Roksandić, D., Triplex Confinium ili o granicama i regijama hrvatske povijesti 15001800, Zagreb 2003.

Roksandić, D., Štefanec, N. (eds.), Constructing Border Societies on the Triplex Confinium, Budapest 2000.

Said, E., Orientalism, London 1978. 
Schmidt-Haberkamp, B. (ed.), Europa und die Türkei im 18. Jahrhundert. Europe and Turkey in the $18^{\text {th }}$ Century, Bonn 2011.

Smith, A. D., The Ethnic Origins of Nations, London, New York 1987.

Suppan, A. (ed.), Zwischen Adria und Karawanken. Deutsche Geschichte im Osten Europas, Berlin 1998.

Šenoa, A., Naša književnost, in: Članci, kritike, govori, zapisi, pisma (ed. Jelčić, D., Špoljar, K.), Zagreb 1978a, pp. 7-13.

Šenoa, A., Turci idu, in: Kanarinčeva ljubovca. Druga knjiga pripovijedaka (ed. Jelčić, D., Špoljar, K.), Zagreb 1978b, sigle TI, pp. 191-247.

Šenoa, A., Vienac zabavi i pouci 30-33, 27 July-17 August 1878.

Wank, S., The Habsburg Empire, in: After Empire. Multi-ethnic Societies and NationBuilding. The Soviet Union and the Russian, Ottoman, and Habsburg Empires (ed. Barkey, K., Hagen, M.), New York, London 1997, pp. 45-57.

Wilson, T., Donan H., Border Identities, Cambridge 1998.

Zernack, K., Zum Problem der nationalen Identität in Ostmitteleuropa, in: Nationales Bewußtsein und kollektive Identität. Studien zur Entwicklung des kollektiven Bewußtseins in der Neuzeit 2 (ed. Berding, H.), Frankfurt a. M. 1994, pp. 176-188.

Žanić, I., The Symbolic Identity of Croatia in the Triangle Crossroads - Bulwark Bridge, in: Myths and Boundaries in South-Eastern Europe (ed. Kolstø, P.), London 2005, pp. 35-76.

Žmegač, V., Krležini evropski obzori. Djelo u komparativnom kontekstu, Zagreb 1986. 
Milka Car

\section{"Nismo bili ne Hrvati ne Iliri niti Slovani, temveč 'cesarsko-kraljevi graničarii' ." \\ O mejnih pojavih v delih Augusta Šenoe in Miroslava Krleže}

Ključne besede: mejni pojavi, Avstro-Ogrska, postimperialna doba, August Šenoa, Miroslav Krleža

Izhajajoč iz teze, da lahko literarna besedila ne le opisujejo realnost, temveč jo tudi konstruirajo, članek analizira izbrana pripovedna, esejistična in poetološka besedila dveh kanoniziranih hrvaških pisateljev, in sicer Augusta Šenoe in Miroslava Krleže. Osredotoča se na prikaz in literarno reprezentacijo različnih mejnih pojavov v avstroogrskem cesarstvu (Šenoa) in njihovega počasnega spreminjanja v postimperialni dobi po prvi svetovni vojni (Krleža). Članek kritično obravnava imperialne narative o vojaški meji, podobe Osmanov v poznem 19. in zgodnjem 20. stoletju ter z njimi povezane nacionalne in homogenizirajoče diskurze, nastale pod vplivom procesov ustvarjanja drugega, ter analizira variacije razumevanja meje in njihove ideološke implikacije. Pri tem se opira na tezo, da so meje konstruirane kot nemogoči poskusi ločevanja sebe od drugega. 


\author{
Milka Car
}

\title{
We "were neither Croatians, nor Illyrians nor Slavs, but "imperial royal frontiersman'". On the phenomenon of the border in August Šenoa and Miroslav Krleža
}

Key words: border phenomena, Austro-Hungarian Empire, post-imperial age, August Šenoa, Miroslav Krleža

Departing from the thesis that literary texts, in addition to their capacity to provide description, also demonstrate potential for construing reality, this paper focuses on the selected narratives, or essayistic and poetological texts written by the canonical Croatian authors August Šenoa and Miroslav Krleža. The paper focuses on the demonstration and literary representation of various border phenomena in the Austro-Hungarian Empire (Šenoa) and their gradual change in the post-imperial age following the Great War (Krleža). By challenging the imperial narrative about the Military Frontier, the image of the Ottomans in the late $19^{\text {th }}$ and early $20^{\text {th }}$ centuries as well as the associated national and homogenizing discourses infused by the processes of Othering, the article analyses a number of variations in the understanding of the border and their ideological implications with special regard to the thesis that borders are construed as impossible endeavours aiming to separate the Self from the Other. 